\title{
MILITARY OPERATIONS OTHER THAN WAR (MOOTW): SYNERGY OF INDONESIAN NATIONAL ARMED FORCES (TNI) AND NATIONAL DISASTER MANAGEMENT AGENCY (BNPB) IN DISASTER MANAGEMENT
}

\author{
Yusa Djuyandi $^{1 *}$, Heri Casnoto ${ }^{2}$, Wahyu Hidayat ${ }^{3}$ \\ ${ }^{1}$ Department of Political Science, Universitas Padjadjaran, Bandung, Indonesia, ${ }^{2}$ Marxism and Political Science Education, \\ Nanjing Normal University, Nanjing, China, ${ }^{3}$ Indonesian Army Command and General Staff College (Seskoad), Bandung, \\ Indonesia. \\ Email: yusa.djuyandi@unpad.ac.id
}

Article History: Received on $19^{\text {th }}$ June, Revised on $23^{\text {rd }}$ August, Published on $26^{\text {th }}$ August 2019

\begin{abstract}
Purpose of the study: The position of Indonesia at the point of three plates of the earth and its location in the tropics makes it vulnerable to disasters. To face the possible disaster, Indonesia Armed Force following its mandate based on Law No. 34 of 2007, synergize with the National Board of Disaster Management to design disaster management cooperation through joint exercise training routinely until 2015.

Methodology: The research used a qualitative method, with primary data in the form of interview and observation, and secondary data were obtained from related documents, such as meeting notes and data on the deployment of troops to the disaster area.

Main Findings: The results show that the synergy between two institutions through the cooperation of personnel training, considering the strengths of each institution that can be mutually reinforcing in disaster management is very important to be continued.

Applications of this study: This study which about military operations other than war (MOOTW) can be useful in every country because of this research look at the synergy between the military and other institutions in disaster management, Social Science, Security Studies and Social Science.

Novelty/Originality of this study: Research on military operations other than war generally looks more at how the military serves as peacekeepers in conflict-prone areas. Very little research has examined the synergy of the military and other institutions in tackling natural disasters.
\end{abstract}

Keywords: Synergy, Disaster Management, Indonesian Armed Force, National Board of Disaster Management

\section{INTRODUCTION}

Indonesia is the largest archipelago in the world with more than 17,500 islands populated with more the 264.0 million people (UNDP, 2017), and surround by 128 active volcanoes make its geographic location on the infamous 'Ring of Fire' (Center for Excellence in Disaster Management and Humanitarian Assistance, 2011). With two distinct monsoonal seasons, these geographic features make it highly vulnerable and disaster-prone and regularly affected by a multitude of seasonal, and other natural disasters, including earthquake and volcanic activity, tsunamis, floods, drought, and landslides. For the three months from July to September 2014, the National Board for Disaster Management (Badan Nasional Penanggulangan Bencana, BNPB) reported 139 natural disasters with 78,484 people affected.

The potential for catastrophic and occasional disasters to make disaster mitigation efforts is important, to minimize the number of victims, loss of property and psychological impacts through mitigation of a series of activities which include prevention, rescue, rehabilitation, and reconstruction.

The Inter-Agency Standing Committee (the global coordination body, with representation of all international humanitarian organizations) has defined a 'disaster' as 'a serious disruption of the functioning of a community or a society causing widespread human, material, economic or environmental losses which exceed the ability of the affected community or society to cope using its own resources' (Brookings Institution, 2011: 55, 58). In other words, the impact of natural disasters is a function of both the severity of the natural hazard and the capacity of the population to deal with it.

Although the UN guidelines for humanitarian and military professionals dealing with civil-military matters that military assets should be used only as a last resort in responding to natural disasters (Inter-Agency Standing Committee, 2008; Secretariat of the Oslo Guidelines, 2009), in many countries - particularly in Asia - the military has become the 'first resort' in time of disaster. This role will increase in the future (Kaplan, 2005). Some civilian humanitarian organizations oppose any expansion of the military's role in humanitarian settings yet the reality is that military forces have specific assets that are needed in major disasters; they often can respond more quickly and on a larger scale than civilian actors.

Due to disaster management, The Government of Indonesia's carried out in a more structured, systematic and continuous code of conduct, through the enactment Law of the Republic of Indonesia, Number 24 of 2007 Concerning Disaster Management (Law No. 24/2007), the country's first and a significant development overarching legislative framework for 
disaster management as the response to the Indian Ocean tsunami in 2004 and the need to review and reform the disaster management system. It assigns the function of BNPB to coordinate the implementation of disaster management in a well planned, integrated, and comprehensive action.

On the other hand, the Indonesian Armed Forces (TentaraNasional Indonesia, TNI) is mandated to respond to disaster and is integrated into the system at the level of first response. The TNI is considered a part of the government disaster response effort and its mandate in disaster response is mentioned in Law No. 34/2004 on the Indonesian Armed Forces. Based on the doctrine of Military Operations Other Than War (MOOTW), TNI coordinate with BNPB helping to respond to the impact of natural disasters, displacement, and delivery of relief aid, and assisting with search and rescue activities.

Indonesian Armed Force has the duty and responsibility to assist the government and society in disaster management, to overcome the disaster, starting from the disaster mitigation until the phase after the disaster, with coordination with BNPB as a focal point of disaster management. Indonesia Armed Force has a more intensive synergy with BNPB through Operational Technical Training and Coordination of Rapid Response for Disaster Relief for military personnel. Through it is provided disaster management education, overcoming the limitations of skills, knowledge, and equipment possessed by personnel Indonesian Armed Force.

The synergies of both institutions initially went well, marked by regular joint exercises from both institutions. However, after 2015 the exercise no longer involves Indonesia Armed Force, consequently taking the initiative to conduct internal training, although only done once a year. This may at times become a factor causing the weak synergy of the Indonesian Armed Force and BNPB in the handling of natural disasters. On the other hand training for the Indonesian Armed Force becomes more and more important, dealing this unit has been established to be a Quick Response Team for Disaster Response (QRTDR) and intended to boost on the readiness of the Indonesian Armed Force in disaster management.

\section{LITERATURE REVIEW}

\section{Synergy}

The word synergy comes from the basic synergy, where the word synergy itself comes from Greek, namely synergies which means working together. Synergy is a form of a process of interaction that produces a harmonious balance so that it can produce something optimum. There are several main conditions for creating synergy, namely trust, effective communication, fast feedback, and creativity (Rustiono, 2016).

Haberberg and Rieple (2008) show synergies as sharing actions in terms of expertise, information, access to financial resources, sales and distribution channels, resources and facilities, the achievement of economies of scale and economies of scope, and sharing systems. Although the scope of this synergy focuses on the economy, there are things that can still be learned from this theory.

According to Covey (2004), synergy is a combination or combination of elements or parts that can produce output better and bigger than done individually, besides a combination of several elements will produce a superior product. Therefore, the synergy in disaster management means the integration of various elements that can produce better and greater output. Covey (2004) adds that synergy will be easy to occur if the existing components are able to think of synergy, there are a common view and mutual respect.

Related to the importance of synergy, even before Covey (1993) once said that the synergy worked together was better than the results of being done individually, besides that a combination of several elements will produce a superior product. The synergy between two or more institutions (Sarundajang, 2006), including synergy between the military institution and other government institution (Djuyandi, Bainus, and Sumadinata, 2018) is also considered important. Synergy is a combination of elements or parts that can produce better or greater expenditure.

\section{Military Operation Other Than War (MOOTW)}

After the end of the cold war, the role of the military began to experience a shift, from those who had previously become combat troops then began to shift to other roles in terms of maintaining peace, overcoming conflicts, and helping civil political authorities in dealing with domestic crises (Segal, 2005). MOOTW does not involve the use or threat of violence but prioritizes the provision of humanitarian assistance and disaster management. In MOOTW, military forces synergize with other institutions/organizations, especially those related to diplomacy, economy, government, even politics and religion (Darwanto, 2015).

Before carrying out operations, the introduction of situations and conditions is usually carried out by units that are satisfied, to determine strengths and expertise, make plans, conduct training and prepare preconditions to achieve operational goals. Special teams for terrain recognition can be formed so that they can be deployed quickly to make field observations, identify characters and threats, communicate with various parties, etc. Mastery of the language and culture of the area is very important to be owned by this special team of predecessors (Darwanto, 2015). 
In view of Rinaldo (1997) The recent use of the Armed Forces, although unprecedented, has begun to enter the realm of non-warfare, such as in disaster relief, humanitarian assistance and peace operations. Military operations are also possible, with close supervision, to temporarily overcome the occurrence of ethnic friction and the handling of refugee populations.

\section{METHODOLOGY}

The research uses qualitative methods with data consists of primary and secondary data. Primary data was obtained from observations which conducted for 2 months (September - October 2017) and interviews with some informants, such as:

1. Yonzikon (Construction Battalion) Commander 13/KE PRCPB TNI, and

2. Head of the National Disaster Management Agency (BNPB).

Observations were made on TNI activities when involved in post-disaster activities, besides that the researcher also observed the types of equipment are used and training carried out by Yonzikon 13/KE PRCPB TNI to help BNPB and government in disaster relief. Secondary data are gained from Yonzikon (Construction Battalion) 13/KE PRCPB TNI and National Disaster Management Agency (BNPB), the data are consists of Yonzikon 13/KE PRCPB TNI involvement in some disasters, meeting notes between Yonzikon 13/KE PRCPB TNI and BNPB.

The process of data analysis begins by reviewing all available data then inductively concluding because the analysis of this study is descriptive. Data analysis is done through three stages:

1. Data reduction: In this stage the researcher conducted a selection process, focusing, simplifying the abstracting of data from field notes. This process takes place throughout the research conducted around a month, starting with making abbreviations, categorizing, focusing themes, determining boundaries of problems and writing memos.

2. Data presentation: This stage was designed to assemble all information regularly so that it is easily seen and understood in a compact form.

3. Drawing conclusions or verification: Various field notes, informant statements, observations then verified to draw conclusions.

\section{DISCUSSION / ANALYSIS}

\section{Indonesia Military Role in Disaster Relief}

Disaster management is a series of efforts covering disaster prevention, emergency response, and rehabilitation activities. The involvement of the Indonesian Armed Force in overcoming the impact of natural disasters has been regulated in Law no. 34 of 2004 about the Indonesian Armed Forces, the tasks of Military Operations Other Than War (MOOTW), by the Indonesia Armed Force are to "help tackle the effects of natural disasters, refugees and humanitarian aid".

The involvement of the military in disaster relief has several perspectives. Controversy exists, however, as to place them within the disaster management cycle and to what extent the military model is appropriate. On the other hand, Carlson $\underline{(2014)}$ believe, learn from America hurricane Katrina disaster, that military should not hold a primary role in disaster relief due to the issues of establishing logistic, communication and medical networks for the victims of a disaster. Instead, a wider role of private sector resources should be open to conduct disaster relief efforts.

In recent years, the role of militaries in responding to disasters relief has grown, as the result of various factors, particularly since 1994, when the Oslo Guidelines occurred as the first document aiming at clarifying the role of the military in international disaster relief assistance, coordination and cooperation between civilian and military actors has grown tremendously (Achleitner, Ebner, and Greindl, 2011). The role of the military in response to a major natural disaster is diverse and is influenced by the "strategic culture" of the contributing countries (Yoshizaki, 2014).

Firstly, deal with an increase in the scale and incidence of disasters and increased interest in disaster response on the part of militaries duty. Climate change and the increase of natural and man-made disasters encourage the use of the military for disaster relief assistance will increase as well.

Secondly, based on their capacity due to its commando doctrine and trained human resources gave assurance toward its presence throughout the country. For this reason, the military is the most dependable and well-organized organization. Considering in disaster operation fast response mechanism is the first thing first. The military plays an important role in disaster management, particularly during large scale catastrophes, due to their special expertise, ability, and resources (Etkin, McBey and Trollope, 2011). Moreover, the military is the only organization able to provide special equipment and personnel for disaster relief operations immediately (Achleitner, Ebner, and Greindl, 2011).

Thirdly, related to public perception, staff morale, relevant training opportunities, and humanitarian operations as a means for armed forces to diversify their role and expertise.

According to the Law No. 34/2004 on the Indonesian Armed Forces, military involvement is officially activated by a request from the civilian authorities. Even though, in many cases the military will take initiatives to take the first respond without any official request from a civilian authority, considering the geographical location of a disaster and the sociopolitical conditions. Based on incident command system, adopted by Indonesia, in an emergency, first responses 
coordinated by all civilian and military organizations particularly comes from the local level, including the decision on the status of the disaster (Articles 7(51), Law 24/2007, and Article 23, Regulation 21/2008).

Emergency funding and resources at the provincial level will be accessed after the affected district declares an emergency. The relevant city mayor or provincial governor subsequently set up the area command headed by an incident commander and comprising the district secretary, the head of the local military base, the head of the local police and the head of the relevant BNPB.

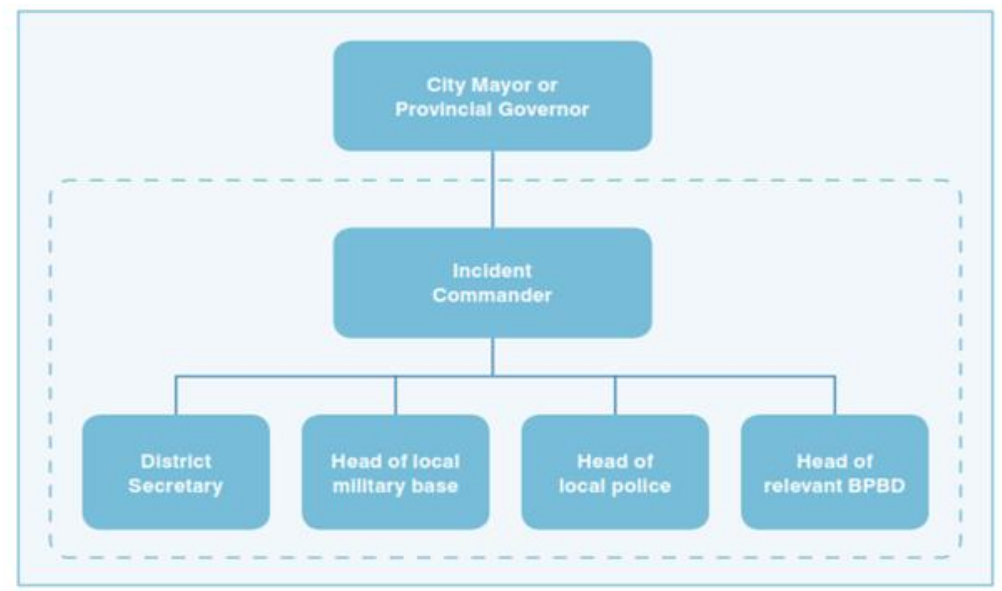

Figure 1: The Incident Command System

Source: Regulation 21/2008 and its elucidation

The military has significant capacity due to its unique geographical structure and substantial human resourcesapproximately 676,500 personnel—guaranteeing its presence throughout the country (World Bank, 2017). For this reason, the military is often a fast, first response mechanism, being present at the scene of a disaster before civilian stakeholders arrive. A member of the military often will be appointed as the incident commander in the event of a disaster, to lead the area command at the provincial and district levels.

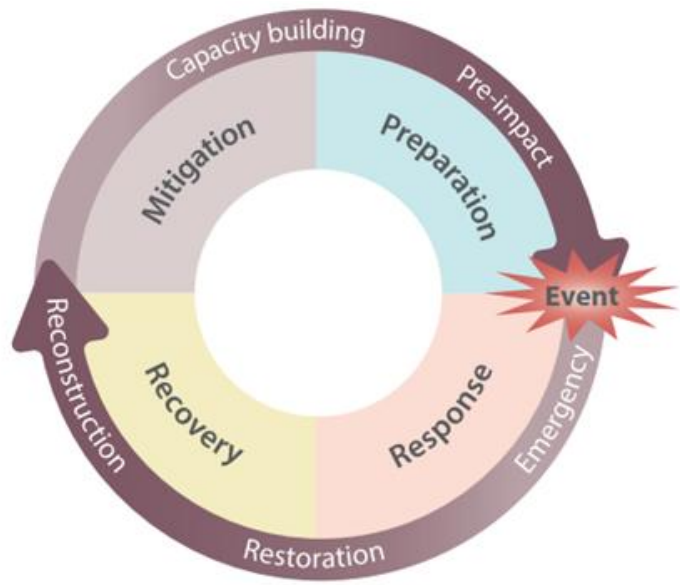

Figure 2: The Disaster Management Cycle

Source: Disaster Relief Operations Overseas: the Military Contribution, 2016

To support disaster relief, Indonesia Armed Force has prepared and commissioned the Yonzikon 13/ KE PRCPB TNI, as the organizational units that participated in disaster response activities. Dealing with the disaster management cycle, the task of Yonzikon 13/ KE PRCPB TNI related to response and recovery activities. Due to disaster relief, Yonzikon 13/ KE PRCPB TNIjoins BNPB cooperates handling the emergency, restoration, and reconstruction. This task placed Indonesia Armed Force under civil order. In this situation, Indonesia Armed Force creates synergy with BNPB to handling disasters relief in better ways.

To analyze the synergy of partnerships between the military and BNPB in natural disaster this research adopts Zineldin and Bredenlőw (2003) theory with indicators: loyalty to partners, maintaining interdependence, integrity, and intensity of relationships, and institutionalization.

1. Partnerships between Organizations 
In the handling of the disaster, the pattern of activities between the Indonesia Armed Force with BNPB requires a pattern that can be used as guidelines to make working together can produce a better result. The pattern is the need for loyalty between partners, with whom it is believed will be able to encourage parties who work together to be able to behave wisely, and rests on the work environment karma in various situations. The loyalty between partners in terms of work together with disaster management is characterized by honesty in recognizing the existence and importance of co-workers, and this condition is particularly important for the implementation of work involving two or more different agencies. With the loyalty to colleagues that leads to honesty in recognizing the importance of colleagues, it will bring a positive impact on the emergence of mutual respect and mutual recognition of the advantages and performance of colleagues.

Related to the need for loyalty aspect among partners in disaster management cooperation, between Indonesia Armed Force relationship with BNPB, good enough embodied in the case of direct communication. As explained by Yonzikon (Construction Battalion) Commander 13/KE PRCPB TNI:

"We are also bridged by the Territorial Assistant of Indonesia Army Strategic Forces. So it makes it easier to cooperate, coordinate and communicate."

In addition, Indonesia Armed Force involvement in disaster management is considered important in addition to having personnel who are competent in working and have high responsibilities, a surplus of the Indonesia Armed Force and this condition can certainly facilitate the process of assistance in the handling of natural disasters if at any time occur in the area, also has the spread troops are almost evenly distributed in each region. The Yonzikon Commander of 13/KE PRCPB TNI explained:

"Technically operational with the distribution of Indonesia Armed Force troops in each region will indeed facilitate the mobilization of troops to help the people affected by the disaster. The existence of mutual understanding and mutual needs can be seen from the pattern of good communication between both parties, ease in cooperation and recognition of the advantages of colleagues."

The emergence of these indicators into a condition that is very supportive and related to the loyalty aspect of the partner. The opposite will happen if there is no loyalty to co-workers, that is, the emergence of an institutional ego that will lead to a debate, and each party will defend its argument and how each in the process of natural disaster relief. The working principle in disaster management encourages Indonesia Armed Force with BNPB, to complement each other in assisting the victims. The allegiance between the Indonesia Armed Force and BNPB will bring about the alignment of work based on a mutually agreed working arrangement.

Efforts to find common ground between two different agencies can be done by the Indonesia Armed Force and BNPB through the orientation of the interests of the nation or society into binders, which support historically also the Indonesia Armed Force, becomes an inseparable part of the Indonesian nation. The relationship between Indonesia Armed Force and BNPB can be analogous to partner in crime, in a positive analogy, in which both support and motivate and share, such as offering assistance. A strong commitment to mutual loyalty among colleagues can also be attached to the working mechanism of an organization as social beings work together and help (Robbins, 1990).

\section{Maintaining Interdependence between the Armed Forces and BNPB}

The paradigm of maintaining interdependence becomes important and must be built jointly among members or institutions incorporated in the work team, the goal is that there is an effort to remind each other and cultivate a sense of caring. The Head of the National Disaster Management Agency (BNPB) told us:

"When a natural disaster occurs, the Indonesia Armed Force is always ready to assist the community and local government. Indonesia Armed Force immediately coordinates with counterparts, such as local government and Regional BNPB, when hearing of natural disasters that hit the community."

That's condition makes the Indonesia Armed Force always reliable in helping people affected by natural disasters. Coordination built between BNPB and Regional BNPB in areas with Indonesia Armed Force always run well and smoothly, this is considered to facilitate the process of cooperation between BNPB personnel with the Indonesia Armed Force. Maintaining interdependence in disaster management is positive and needs to be done, and between the cooperation between BNPB and Indonesia Armed Force, there has been awakened in awareness to maintain interdependence. It is founded that the condition where the success in natural disaster relief is obtained from the cooperation of several parties, as between BNPB with Indonesia Armed Force, local government and national police.

The importance of maintaining interdependence in cooperation can be analyzed from the view of Tracy (2006) which states that teamwork is a managed activity and carried out a group of people who are members of one organization. Teamwork can enhance cooperation and communication within and between parts of the organization. Usually, the teamwork consists of people who have different skills so that made the strength in achieving the job objectives.

The principle of interdependence in cooperation avoids the existence of a one-sided pattern of work, as well as work as in an ecosystem where interrelationship occurs resulting in a symbiotic mutualism. In sociology, the Indonesia Armed Force and BNPB as part of a social organization, which consists of many human beings as living beings, are considered unable to 
live alone. They depend on other social organizations and the environment. The interdependence relationship between Indonesia Armed Force and BNPB belongs to pooled interdependence (Thompson, 1967) where the organizational units are not dependent on each other in carrying out daily activities but are dependent on the satisfactory work of each unit to a final result. This is driven by the relationship between the two institutions, not in the course of execution of duties or daily work that cooperation between the two institutions is done only when a natural disaster occurs, also requires fast and serious handling; this indicates the purpose that must be completed by both organizations. When disaster management and handling are done quickly, it will generally lead to some sort of satisfaction in the final results, which causes the dependence between the two to fall into a pooled interdependence.

Adjustment with partners to build synergy between Indonesia Armed Force and BNPB is defined as continuous interaction with oneself, with others, and with your world (Calhoun and Acocella in Sobur, 2003: 526). The recognition from BNPB that the role of Indonesia Armed Force is needed in the process of handling and handling disaster becomes a positive indication of the trust of other institutions to the Indonesia Armed Force. Cooperation between BNPB and Indonesia Armed Force can adapt itself under the demands and needs of BNPB. The communications built by the Indonesia Armed Force went well.

The success of the Indonesia Armed Force in making the adjustment process with the partner, in addition to the success of building communication and socialization, is also based on the ability to conform to a norm. Although Indonesia Armed Force is a military institution, that Indonesia Armed Force is willing to assist disaster-affected communities and coordinate with related agencies in disaster management. This ability arises because of the compromise of a norm, the norm of humanity. The encouragement of the norms of humanity changed the attitude of Indonesia Armed Force personnel by giving rise to the nature of humanity. Such as assisting BNPB in searching for natural disaster victims, providing medical and food aid, socializing about disaster-prone areas.

By interpreting conformity as a conformity effort, it implies that the Indonesia Armed Force is under intense pressure from within itself and the environment to always be able to avoid moral, social, or emotional deviations from behavior. Thus, the Indonesia Armed Force in assisting is based on humanitarian motives, not on other motives, and therefore the Indonesia Armed Force efforts to assist also need to be tailored to the needs of their co-workers, namely BNPB. This reason is based on the main authority of disaster management in the hands of BNPB, and the position of the Indonesia Armed Force is as the seconded party.

\section{Integrity and Intensity of Relationships}

Integrity is one of the most important attributes that must be owned by the institution, and a concept related to consistency in actions, values, methods, measures, principles, expectations and the resulting things. Welch (2005) defines, integrity is a vague word (vague) because People who have integrity tell the truth, and those people hold their word, are responsible for their actions in the past, admitting mistake them and correct them. They know the laws of their country and obey them. They play to win right (clean), according to the rules.

Integrity in building synergy between Indonesia Armed Force and BNPB in disaster management is very important. Without integrity, it will be difficult for anyone to be able to determine and take actions, methods, measures and other things that resulted in a disaster response effort. The existence of integrity, makes the Indonesia Armed Force feel moved to provide assistance and humanitarian assistance for victims of natural disasters. The Indonesia Armed Force's integrity in providing assistance to BNPB and helping victims of natural disasters can be seen from the presence of strong and consistent characters, the Indonesia Armed Force is consistently always present to the government, BNPB and the community when natural disasters occur.

The integrity of the Indonesia Armed Force, which was assigned as a Quick Response Force for Disaster Management of the Indonesia Armed Force, in assisting disaster mitigation also cannot be doubted. As explained by Yonzikon Commander of 13/KE PRCPB TNI about the readiness of the military to assist in handling disasters:

"Indonesia Armed Force personnel are involved in disaster management and the involvement and assistance provided by Indonesia Armed Force personnel in disaster management is then broken into several sections that have been jointly established between Indonesia Armed Force and BNPB, such as those entering the rapid reaction team, logistics section and some evacuation team."

In another side the BNPB Head also explained:

"In the case of Indonesia Armed Force's integrity to comply with rules and mechanisms applicable when disaster management can be seen from the Indonesia Armed Force's readiness to assist and report on disaster management activities to BNPB."

This proof of integrity is important because Indonesia Armed Force is a state tool that requires professional attitude and commitment. This is apparent in the process of disaster management usually Indonesia Armed Force personnel merged in the organizational structure that has been prepared by BNPB, as the manager and coordinator in the handling and the field of agencies consist of Indonesia Armed Force, Police, Red Cross, Public Works Department. 
The integrity of the Indonesia Armed Force in disaster management refers to the commitment of Indonesia Armed Force unity with the people and also the commitment to become a professional Indonesia Armed Force by complying with all applicable laws and regulations. In the Army perception, the needs of the community are very important to be considered and need to be prioritized to support the activities of social life. In this case, the Indonesia Armed Force has cooperated with the BNPB and all other Nations components to further optimize the role to assist the communities affected by natural disasters.

Concerning the good communication and coordination process conducted between Indonesia Armed Force with BNPB, it can be said also that the intensity of the relationship between the two institutions went well. At least this is also acknowledged by informants from the BNPB who said that communication and coordination between BNPB and Indonesia Armed Force during the implementation of disaster management tasks did not experience obstacles and running well, Indonesia Armed Force assistance also provide many benefits in accelerating the evacuation process. The invitations for joint training activities organized by BNPB implemented 2-3 times in one year indicate the existence of good relationship intensity between the two institutions in building synergy in the disaster management process.

Through training with the intensity of relationships built by the two institutions led to the unity of attitudes and patterns of cooperation also led to the existence of a positive reciprocal relationship, and even complement each other like BNPB's use of appliance and the use of heavy equipment owned by the Indonesia Armed Force to evacuate or perform other disaster management tasks. It appears that between the two institutions has arisen a pattern of symbiotic relationship mutualism, which is mutual need each other. This pattern of relationships can be difficult if there is no good relationship intensity.

\section{Institutionalization}

The central idea of institutional theory is that organizations are shaped by the surrounding institutional environment. Observation of the organization should be seen as the totality of symbols, languages, or rituals that surround it. Institutionalism, therefore, rejects the notion that its larger institutional and institutional contexts can be understood by aggregating observations of individual behaviour (Skelley, 2000). Skelley says that for an institutionalist, the whole is bigger than the number of individuals (human parts).

The distinguishing feature of the institutional paradigm is in looking at the nature of the organization. Their idea is that the organization is more a social system whose shape is influenced by the broader symbolic, cultural and social aspects of the organization. Scott (1987) says that constitutional views and instrumentalities are complementary (complementary). Nevertheless, studies by institutionalists suggest that organizational structure should not be understood as a rational adaptation of contingent factors in the instrumentalist technical mode, but concerning norms, legitimacy obligations, myths, beliefs and technical factors of instrumentality (Donaldson, 2000).

Institutional analysis tends to see social parameters (societal parameters). DiMaggio and Powell (1983) believe that organizations are formed by forces outside themselves through the process of mimicry and compliance. DiMaggio and Powell Theory is an example of the institutionalist concept of amorphism found in the institutional paradigm in which contains the kinds of theories and concepts that one and the other can be different.

Parsons (in Malarangeng, 2010: 132) also argues that institutionalization is the process by which organizations and procedures derive value and stability. "With the institutionalization will bring about a similar and rhythmic pattern of movement, this is what Huntington later said that to measure institutionalization one of them can be seen from the adaptability. Without adaptability, it is difficult for organizations to create a pattern of co-operation and rhythmic.

Based on the institutionalization concepts, the adaptability to create the same and rhythmic pattern of cooperation from an organization can be done by providing space for people in the institution to get training and education to the intended conditions. To create the synergy of Indonesia Armed Force and BNPB in disaster management, institutionalization becomes an important matter to be observed and done by Indonesia Armed Force. As explained by Yonzikon commander:

"Concerning training and education in disaster management as yet no special training program as an Indonesia Armed Force, plans will be submitted in the 2018 program."

The absence of joint exercises shows the weaknesses in the aspect of institutionalization. The involvement of the BNPB can also help to carry out strict planning and planning in disaster management, this is related to the complexity of the disaster problem. Training that is not done jointly will make the resulting work is less integrated and the countermeasures are not based on systematic and planned steps, resulting in overlapping work and even important steps that are not handled.

\section{The synergy between Yonzikon 13/KE PRCPB TNI and BNPB}

In handling disasters in Indonesia, encourage the synergy between the military and BNPB. Harwood (2000: 523-529) quotes Castell, Gregory, Hindle, James, and Ragsdall who write that "synergy comes from the Greek word synergies which means working together. This demands a platform for participation through the development of dialogues, between disciplines and people, the very stuff of systems thinking." Naudé, Heyns, Bester, Puig, and Tucker (2002: 2) define synergy as the ability of two or more business units or companies to generate greater value working together than they would work apart. Finally, the integrative definition of synergy as a concept that describes the systemic processes whereby 
business units of diverse, complex organizations will generate greater value through working as one system than working as separate entities (Gerhard, Schurink, and Roodt, 2007).

That synergy involves military and civilian relations. Huntington (1957: 83-85) objective civilian control focused on maximizing and strengthening military professionalism, namely by the division of power between military groups and civilian groups with the ultimate goal that military groups could focus on becoming a state tool to maintain defense and security.

Unlike Huntington, Janowitz (in Zippwald, 2011: 10) sees it from the perspective of sociology, where professional soldiers must be above politics even above politics, even though the reality is not always so. To continue as a professional force and be able to answer a dilemma in the future, the military elite must transform itself into the power of the constitution. Furthermore, Janowitz revealed that as a constitutional power, the military would guarantee professionalism and its integration with the people. Janowitz believes that the military and the people should integrate to realize better civilmilitary relations. This according to Huntington reflects subjective civilian control, whereas Janowitz who believes that there is a vague line between civilians and the military precisely negates Huntington's theory which believes that the military must stand apart and be autonomous from civil society in order to maintain its professionalism. Whatever the difference, both agree that the military should maintain its professionalism.

Problems occur in building the synergy of disaster management between Indonesia Armed Force and BNPB, which requires comprehensive problem-solving. The synergy between the Indonesia Armed Force with BNPB being important due to disaster management requires fast and precise handling, this situation will not be achieved if the problems disrupt the synergy of both institutions. By using SWOT Analysis, this situation can be mapped. The result shows that there are several strengths of those synergies such as (1) good communication and coordination between Indonesia Armed Force and BNPB; (2) BNPB response that the Indonesia Armed Force has personnel who are competent in working and have high responsibilities; (3) Complementary working principles among the institutions involves: BNPB, National Police and Local Government; (4) the ability of Indonesia Armed Force to adopt when doing work with BNPB, among others is the recognition that control is in BNPB. On the other hand, the synergy facing several disadvantages such as (1) Indonesia Armed Force does not have a specific training program as a TNCP PRCPB; (2) The disaster management training program depends on BNPB; (3) Internal training is done once a year; (4) Internal training does not involve BNPB; (5) After 2015 there is no more training with BNPB with Indonesia Armed Force. On the other side, there is an opportunity related to submission of special training of the Indonesia Armed Force for 2018. And the threat is co-benefits that are not in accordance with the Indonesia Armed Force Law and are not under the coordination of BNPB may lead to Indonesia Armed Force incompetence (Andrews, 2008).

From the SWOT analysis, it can be identified several forces related to the synergy of disaster management between Indonesia Armed Force and BNPB. Among the first few strength is the existence of good communication and coordination between Indonesia Armed Force and BNPB. Relationships and communication in an effort to build synergy are important, without communication, there will be no synergy or cooperation. The good relationship and communication between Indonesia Armed Force and BNPB in the disaster management process should be maintained, not only in the fieldwork but also in some other activities, such as joint training.

The existence of a second force, a response from the BNPB that the Indonesia Armed Force has personnel who are competent in working and have high responsibilities, is an indication of a positive response from colleagues. A positive response is needed in order to build trust relationships between the two organizations, it is also necessary to keep the future synergies of disaster management in good shape. The strength is also related to the third power, namely the establishment of a complementary working principle between several institutions such as BNPB. When some institutions are able to cooperate well in carrying out a job then the results achieved will be more in line with expectations.

Indonesia Armed Force's ability to adopt when working with BNPB can be seen from the recognition of the Indonesia Armed Force that the control of disaster management organizers is at BNPB. The recognition of the Indonesia Armed Force demonstrates a strong commitment from the Indonesia Armed Force to become a professional institution. As a state instrument in charge of safeguarding national defense, Non-War Military Operation needs to be coordinated with the competent authorities, not only to maintain good interagency relationships but also to maintain the professionalism of the Indonesia Armed Force that must base its work under the law. This commitment to becoming a professional is then the strength of the Indonesia Armed Force to build synergy with BNPB.

The ability of the Army to build synergy with BNBP also shows that internal reforms of the Indonesia Armed Force, which have been carried out for almost two decades, have factually responded to the demands of society. Currently, the Armed Forces are continuing their efforts to continue the demands of the community gradually, covering both the structural and cultural aspects. This gradual effort aims at realizing a solid, reliable, and professional Indonesia Armed Force posture.

The Armed Forces structural and cultural reforms that have been carried out by organizational reform, doctrine, education and training and the fulfillment of the welfare of soldiers. The next important thing concerning the effort to build synergy with BNPB is the commitment to maintain the consensus of cultural reform in the internal body of the Indonesia Armed Force, which is related to the willingness and consistency of implementing the policy of non-double function doctrine until 
now. The ability of the Army, in maintaining consensus and reform commitment in the task has a positive impact on the performance of the task. Starting from the time of consensus laid down for internal reforms, for the Indonesia Armed Force is how to put the national paradigm and interest in carrying out the mandated tasks. As explained by the Yonzikon commanders:

Although in building the synergy between the Indonesia Army and BNPB there are many advantages or strengths, on the other hand, there are also many shortcomings or weaknesses that can hamper the development effort of disaster management synergy between Indonesia Armed Force and BNPB. The first deficiency, Indonesia Armed Force does not have a specific training program as the Rescue Team. The absence of a special training program may be one of the inhibiting factors of the Indonesia Armed Force aid in the handling of natural disasters.

The absence of a special training program followed by Indonesia Armed Force members is further enhanced by the Indonesia Armed Force dependency on disaster prevention programs from BNPB. This dependence can not only be an obstacle in upgrading the personnel of Indonesia Armed Force, but it can also show that there is still a lack of effort to build synergy between Indonesia Armed Force, and BNPB.

In the case of internal training conducted only by Indonesia Armed Force as much as once a year, and not involving BNPB in the internal training, may lead to potential ineffectiveness of the exercise. Based on the statement of BNPB Head:

"Ideally, internal training in disaster management should involve or invite BNPB as an instructor and should be done at least two times a year. As before 2015, BNPB involves Indonesia Armed Force to participate in several joint exercises with the frequency of 2-3 per year. Involving BNPB in internal training is important so that Indonesia Armed Force personnel can find out the latest trends in dealing with disaster management issues, as well as to gain new knowledge and improve their capability in the disaster management process."

The reopening of joint training between BNPB and Indonesia Armed Force, after the last time in 2015, is another shortcoming that needs to be solved by the two institutions. Building synergy in disaster management needs to be done through a planned and sustainable activity; the breaking of joint exercises in one position will complicate the implementation of tasks in the field. It is different if between two or more organizations have routinely conducted joint exercises and coordination although in a safe condition when in a situation where the organization or institution is required it will facilitate the acceleration of cooperation.

In the shortcomings and weaknesses, some opportunities can be used by the Indonesia Armed Force and BNPB to strengthen the synergy of the two agencies for natural disaster management, namely the submission of special training of Indonesia Armed Force for 2018. The Head of BNPB explained:

"If the submission of special training this got approval from the Army leadership then the intensity and model of disaster management training can be further improved, especially by involving BNPB."

Later the joint disaster management training model can be a simulation of community anticipation, government apparatus, BNPB, Indonesia Armed Force and National Police when emerged the threat of natural disaster and post-natural disaster.

Looking at the above analysis can be re-emphasized that the importance of synergy between BNPB and Indonesia Armed Force in the handling of natural disasters. However, there is one condition that the Indonesia Armed Force, need to pay attention to, in cooperation or synergy with other institutions, including BNPB. In the perspective of the researcher that the assistance of the Indonesia Armed Force in the handling of disasters must be in accordance with the law, the assistance that is not in accordance with the Indonesia Armed Force Law and not under the coordination of BNPB could lead to Indonesia Armed Force incompetence and this becomes a threat that at any time can make the Indonesia Armed Force lose the trust of the people.

The synergy between Indonesia Armed Force and BNPB becomes more and more important to deal with direct contact to the interests and needs of the community, whether before or after the occurrence of natural disasters. As a part of the people's army that comes from the people, the Indonesia Armed Force needs to position itself parallel to the people and be in the midst of the people, so that when the people need help, the Indonesia Armed Force must be ready to help. Although the task of handling natural disasters is the domain or main task of BNPB, because the Indonesia Armed Force is united with the people, then the Indonesia Armed Force has a moral responsibility to help the people who are affected by the disaster. Indonesia Armed Force in a position in the event of a natural disaster must be ready to help the community and BNPB.

In the case of Indonesia Armed Force assistance against BNPB in the event of a natural disaster, that it has been regulated in Article 7 of Law 34 of 2004 On the Indonesia Armed Force. The assistance of Indonesia Armed Force in the handling of natural disasters based on the Indonesia Armed ForceLaw is entered into the category of basic tasks of non-war military operation, where Indonesia Armed Force is required to coordinate with counterpart institutions, may be considered in violation of applicable legislation because there is a condition in which the duties performed are not within the civil or military emergency sphere. 


\section{CONCLUSION}

Implementation of natural disaster management by Indonesia Armed Force in the frame Non-War Military Operation based on cooperation and coordination with the National Board of Disaster Management (BNPB) as the national body formed by the government to anticipate and deal with the impact of the occurrence in the country. When the BNPB does not involve either as instructors or trainees, in the internal disaster management training conducted by Indonesia Armed Force, also indicates the beginning of the discovery of problems that can disturb the synergy of the two institutions. The need for BNPB of internal training based on consideration of knowledge and authority of BNPB in handling disasters, including in preparing resources to anticipate in case of natural disasters. Due to enhancing relations between the two institutions it is emergence the potential cooperation between the Armed Force and BNPB.

In handling disasters in Indonesia, the domination of civilians over the military still seems to have not been fully implemented. In-depth traces of military power during the New Order, which was more than 30 years and even 20 years since the reform movement in 1998, still show the military as a civilian party. Even in handling disasters, the military can often go down directly and act without waiting for requests from civil authorities. Furthermore, this creates the impression that the synergy between the military and civilians must still be improved. The synergies that have occurred so far are seen as false as long as the two parties still rely on each other. In this case, the military still relies on civil training, in the form of training from BNPB.

\section{LIMITATION AND STUDY FORWARD}

This research focuses on military operations other than war-related to how the military plays a role in handling natural disasters and synergizes with other state institutions related to disaster management (BNPB). The researcher realized that military operations other than war in handling other cases may have different dimensions, therefore the researchers hope that there will be other researchers who examine the role of the military in military operations other than war.

\section{ACKNOWLEDGMENT}

We are would like to say thank you to Yonzikon (Construction Battalion) Commander 13/KE PRCPB TNI, and Head of the National Disaster Management Agency (BNPB), for their contribution as an informant, also to the Army Agency Staff and Command School (Seskoad), Indonesia, and Universitas Padjadjaran for their support in assisting the research process.

\section{REFERENCES}

1. Achleitner, T., Ebner, G., and Greindl, G. (Eds.). (2011).International Disaster Relief Assistance - What Role for the Military?.Vienna: United Nations Information Service (UNIS).

2. Andrews, B.M. (2008).Patterns of Civil-Military Relations in Democracies. Fort Leavenworth, Kansas: School of Advanced Military Studies.

3. Badan Nasional Penanggulangan Bencana (BNPB). (2017). Sejarahdan VisiMisi BNPB. Source: https://www.bnpb.go.id/home/sejarah. [Accessed on February $23^{\text {rd }}, 2018$ ].

4. Gerhard, B., Schurink, W., and Roodt, G. (2007).Towards A Substantive Theory of Synergy.SA Journal of Human Resource Management, 5(2): 9-19. https://doi.org/10.4102/sajhrm.v5i2.115

5. Brookings-Bern Project on Internal Displacement.(2011).Inter-Agency Standing Committee (IASC) Operational Guidelines on the Protection of Persons in Situations of Natural Disasters. Washington DC: Brookings Institution.

6. Carlson, C.A. (2014). Private-public disaster relief: what is the military's role?. Monterey, California: Naval Postgraduate School.

7. Center for Excellence in Disaster Management and Humanitarian Assistance. (2011).Country Disaster Response Handbook: Indonesia. Hawaii: Center for Excellence in Disaster Management and Humanitarian Assistance.

8. Covey, Stephen R. (1993). Principles Centered Leadership. New York: Fireside.

9. Covey, Stephen R. (2004). The 7 Habits of Highly Effective People. New York: Simon and Schuster.

10. Creswell, J.W. (2003). Research Design: Qualitative, Quantitative and Mixed Methods approaches (2nd ed.). Thousand Oaks: Sage.

11. Darwanto, H. (2015). OperasiMiliterSelainPerang. Jakarta: KementerianPertahanan. Retrieved from https://www.kemhan.go.id/wp-content/uploads/2015/12/bab47c96d3592e7652310529454b1107.pdf.

12. DiMaggio, P.J., and Powell, W.W. (1983). The Iron Cage Revisited: Institutional Isomorphism and Collective Rationality in Organizational Fields. American Sociological Review, 48(2): 147-160. https://doi.org/10.2307/2095101

13. Djuyandi, Y., Bainus, A., \& Sumadinata, W.S. (2018). Synergy Between Regional Command Unit of Indonesian National Army (TNI AD) and Local Government in Encouraging the Spirit of State Defense. Central European Journal of International and Security Studies, 12(4): 127-143.

14. Donaldson, T.L. (2000). Religious Rivaliries and the Struggle for Success in Caesarea Maritima. Waterloo, ON: Wilfrid Laurier University Press. 
15. Etkin, D., Mcbey, K., and Trollope, C. (2011). The Military and Disaster Management: A Canadian Perspective on The Issue. Canadian Disaster Management Textbook: Chapter 5b. Retrieved from https://www.crhnet.ca/sites/default/files/library/Etkin.pdf.

16. Haberberg, A., and Rieple, A. (2008). Strategic Management: Theory and Application. Oxford: Oxford University Press.

17. Harwood, C. J. (2000). Review of "Synergy matters: Working with systems in the twenty-first century" by A.M. Castell, A.J. Gregory, G.A., Hindle, M.E., James and G. Ragsdall (Eds). Kybernetes, 29(4): 523-529. https://doi.org/10.1108/k.2000.29.4.523.4

18. Huntington, S. (1957). The Soldier and the State; the Theory and Politics of Civil-Military Relations. Cambridge: Belknap Press of Harvard University Press.

19. Kaplan, R. (2005). US Forces: The World's Best Relief Group. New York Times, October 12th, 2005.

20. Law of the Republic of Indonesia No. 34 of 2004 on the Indonesian Armed Forces

21. Law, of the Republic of Indonesia No. 24 of 2007 on the Disaster Management

22. Malarangeng, R. (2010). From Heaven: A Collection of Essays on People, Society and Power. Jakarta: PT. Gramedia.

23. Naudé, A., Heyns, D., Bester, C., Puig, J. \& Tucker, G. (2002). Synergies within Barloworld. Unpublished manuscript. Johannesburg: Barloworld Executive Development Programme, Gordon Institute of Business Science.

24. Regulation No. 21/2008 on the Disaster Relief.

25. Robbins, S.P. (1990). Organization Theory: Structure, Design, and Applications. New Jersey: Prentice Hall.

26. Rinaldo, R.J. (1997). Warfighting and Peace Ops: Do Real Soldiers Do MOOTW?.Joint Force Quarterly, Winter 96-97, Number 14, 111-116.

27. Rustiono, D. (2016). MewujudkanSinergidalamOrganisasi. Semarang: UniversitasNegeri Semarang. Retreieved from: http://unnes.ac.id/gagasan/mewujudkan-sinergi-organisasi/,

28. Sarundajang, S.H. (2006).Rencana Pembangunan JangkaMenengah Daerah (RPJMD) Provinsi Sulawesi Utara tahun 2005-2010. Manado: BadanPerencanaan Pembangunan Daerah, Provinsi Sulawesi Utara.

29. Segal, Hugh. (2005). Geopolitical Integrity. Montreal: Institute for Research on Public Policy (IRPP).

30. Scott, W.R. (1987). The Adolescence of Institutional Theory. Administrative Science Quarterly, 32(4): $493-511$. DOI: http://dx.doi.org/10.2307/2392880.

31. Sobur, A. (2003). PsikologiUmum. Bandung: PustakaSetia.

32. Skelley, B.D. (2000). Radical Institutionalism and Public Administration: A Review of Nils Brunsson's Contributions to Understanding Public Sector Organizations. Public Administration and Management: An Interactive Journal, 5(3): 112-122.

33. Thompson, J. D. (1967). Organizations in Action. London: Transaction Publisher.

34. Tracy, B. (2006). PemimpinSukses (Successful Leader), Sixth Edition. Translator: Suharsono. Jakarta: DelapatrasaPustaka.

35. United Nations Development Programme (UNDP). (2017). Indonesia Country Profile, Retrieved fromhttp://hdr.undp.org/en/countries/profiles/IDN\#. [Accessed on February $7^{\text {th }}, 2018$ ]. [Done]

36. United Nations, and Inter-Agency Standing Committee. (2008). Civil-Military Guidelines and Reference for Complex Emergencies. New York: UN Office for the Coordination of Humanitarian Affairs. Retrieved from https://www.unocha.org/sites/dms/Documents/02.\%20Civil\%20Military\%20Guidelines\%20and\%20Reference\%2 Ofor\%20Complex\%20Emergencies.pdf

37. United Nations Office for the Coordination of Humanitarian Affairs (OCHA). (2006). Guidelines on the Use of Military and Civil Defence Assets to Support United Nations Humanitarian Activities in Complex Emergencies. Retreieved from https://www.unocha.org/publication/guidelines-use-military-and-civil-defence-assets-supportunited-nations-humanitarian .

38. Welch, J. (2005). Winning. New York: Harper-Collins.

39. World Bank. (2017). World Military Indicator. Retrieved from http://data.worldbank.org/indicator/MS.MIL.TOTL.P1

40. Yoshizaki, T. (2014). The Military's Role in Disaster Relief Operations: A Japanese Perspective. National Institute for Defense Studies (NIDS), Japan. Retrieved from www.nids.mod.go.jp/english/event/symposium/pdf/2011/e_06.pdf

41. Zineldin, M., and Bredenlöw, T. (2003). Strategic alliance: Synergies and Challenges - A case of strategic outsourcing relationship "SOUR". International Journal of Physical Distribution and Logistics Management, 33(5): 449-464. https://doi.org/10.1108/09600030310482004

42. Zippwald, S. (2011). Effective Civil-Military Relations: A Necessary Ingredient for Success in America's Future Strategic Environment. Norfolk VA.: Thesis Joint Forces Staff (JFS) College, MS in Campaign Planning and Strategy. 